Chirurgia (2021) 116: 473-479

No. 4 , July - August

Copyright@ Celsius

http://dx.doi.org/10.21614/chirurgia.116.4.473

\title{
The Use of Mucolytic Agent in Percutaneous Drainage of Liver Abscess: A Case-Series Analysis
}

\author{
Ramona Cadar', Ana-Maria Trofin ${ }^{1,2}$, Mihai Zabara ${ }^{1,2}$, Alexandru Nastase ${ }^{1}$, Vasile Fotea ${ }^{3,4}$, \\ Corina Lupascu-Ursulescu ${ }^{3,4^{*}}$, Cristian Livadaru ${ }^{3,4}$, Cristian Lupascu ${ }^{1,2}$ \\ 'Department of General Surgery and Liver Transplantation, St. Spiridon University Hospital lasi, Romania \\ ${ }^{2}$ Surgery Department, Faculty of Medicine, Grigore T. Popa University of Medicine and Pharmacy lasi, Romania \\ ${ }^{3}$ Department of Radiology and Interventional Radiology, St. Spiridon University Hospital Iasi, Romania \\ ${ }^{4}$ Radiology Department, Faculty of General Medicine, Grigore T. Popa University of Medicine and Pharmacy lasi, Romania
}

*Corresponding author: Corina Lupascu-Ursulescu, MD, PhD Department of Radiology and Interventional Radiology Saint Spiridon UniversityHospital lasi 700115, lasi, Romania

E-mail: corina.ursulescu@gmail.com

\section{Rezumat}

Drenajul percutan al abceselor hepatice cu instilare intracavitară de agent mucolitic: analiza unei serii de cazuri

Context: Abcesul hepatic este un proces supurativ rar, dar cu potențial fatal. Există o tendință generală de a opta inițial pentru tratamentul minim invaziv, cum ar fi antibioterapie cu spectru larg şi drenaj percutan. Abcesele multiloculate, multiple sau incomplet lichefiate limitează de multe ori eficiența drenajului percutan. Scopul acestui studiu este de a evalua eficacitatea drenajului percutan al abceselor hepatice şi a instilării intracavitare a unui agent mucolitic.

Material şi Metodă: Din baza de date a Clinicii chirurgicale I-II, Spitalul Sf. Spiridon Iaşi, am identificat pacienții cu abces hepatic tratați prin drenaj percutan ghidat ecografic în perioada 2015-2020, la care s-a instilat intracavitar agent mucolitic. Datele despre caracteristicile abcesului, explorările imagistice, tehnica drenajului, markerii inflamatori şi evoluția clinică au fost introduse intr-o bază de date şi analizate.

Rezultate: Douăzeci şi unu pacienți cu abcese hepatice multiloculate, cu dimensiuni de $8-17 \mathrm{~cm}$, au fost drenați percutan, cu anestezie locală, sub ghidaj ecografic. Din aspiratul intracavitar, bacteria izolată predominant a fost Klebsiella pneumoniae; 2 pacienți au prezentat infecții fungice. Pe cateterul de drenaj, de $12 \mathrm{~F}$ sau $14 \mathrm{~F}$, s-a instilat intracavitar zilnic, acetilcisteina în diluție 1: 1 cu soluție salină, până la rezoluția clinică şi radiologică, obținută în 14 - 29 de zile. Două cazuri au necesitat drenarea unei 
cavități reziduale necomunicante. $\mathrm{Nu}$ s-au înregistrat complicații, decese periprocedurale sau recidivă la 3 luni de supraveghere.

Concluzii: Drenajul percutan este eficient chiar şi în gestionarea abceselor hepatice multiloculate, utilizarea instilării intracavitare a substanțelor mucolitice favorizând resorbția cavității si evolutia favorabilă.

Cuvinte cheie: abces, ficat, drenaj, mucolitic

\section{Abstract}

Background:Liver abscess is a scarce but potentially fatal suppurative process. There is a general tendency for minimally invasive treatment, such as broad-spectrum antibiotherapy and percutaneous drainage. Multiloculated, multiple or incompletely liquefied abscesses often limit the efficacy of percutaneous drainage. This study aims to assess the effectiveness of percutaneous drainage and intracavitary instillation of a mucolytic agent for liver abscesses.

Material and Method: From our department database, we have identified patients with liver abscess admitted during the period 2015-2020, treated by ultrasound-guided percutaneous drainage and intracavitary instillation of mucolytic agent. Data regarding imaging appearance, drainage technique, inflammatory markers and clinical course were assessed.

Results: Twenty-one patients with multiloculated liver abscesses, sized 8 to $17 \mathrm{~cm}$, were percutaneously drained, with local anaesthesia, under ultrasound guidance. The bacteriological exam of the aspirate showed bacterial infection in 19 cases, mostly Klebsiella pneumoniae, and 2 fungal infections. Acetylcysteine in dilution 1: 1 with saline was instilled daily on the $12 \mathrm{~F}$ or $14 \mathrm{~F}$ drainage catheter. Clinical and radiological resolution was achieved within 14 to 29 days. Two cases required supplementary drainage of a non-communicating residual cavity. There were no complications, periprocedural deaths or relapse at 3 months follow-up.

Conclusions: Percutaneous drainage is effective even in the management of multiloculated liver abscesses, facilitated by the use of intracavitary mucolytic agent.

Key words: abscess, liver, drainage, mucolytic agent

\section{Introduction}

Liver abscesses are rare but potentially fatal disease, consequence of a suppurative processes affecting hepatic parenchyma by different pathways. The septic process is followed by the formation of intrahepatic, single or multiple purulent collections (1). The pathogenic agent involved in the development of liver abscesses may be fungal, bacterial or parasitic (2). The main bacterias isolated in liver abscess are Escherichia coli, Klebsiella pneumoniae, Staphylococcus aureus or Enterococcus faecalis, all associated with solitary or multiple abscesses (3). The incidence is 8-16 cases per 100,000 , with a death rate of $2-12 \%$ in the developed countries $(4,5)$. Different paths of bacterial dissemination were described, the ascendent route through the biliary tract or portal flow, via hepatic artery, from the surrounding organs or idiopathic causes (6). The therapeutic strategies for liver abscesses are not standardized. The intravenous antibiotherapy is the gold standard but may be insufficient as a single treatment (3). The efficiency of percutaneous treatment (aspiration combined or not with catheter drainage depending on abscess size) was proved in partially liquefied liver abscesses $(4,5,7)$. The main drawback is the slow resolution of the abscess, incomplete evacuation, and the risk of recurrence (8). The cut-off size for a liver 
abscess to be successfully drained percutaneously is between 3 and $6 \mathrm{~cm}$ (9). Multiple or multiloculate abscesses are recognised complex situations, making the drainage more technical difficult, with lower chances of success, and longer time for resolution (10). For these situations, the use of adjunct fibrinolytic agents was advocated (10).

We analyzed our department experience with percutaneous drainage of the multiloculate liver abscesses and the intracavitary instillation of a mucolytic agent.

\section{Material and Methods}

Our department database was searched for the period 2015-2020, to identify the patients admitted with liver abscess and treated by ultrasound-guided percutaneous drainage. From these, cases with intracavitary instillation of mucolytic agent were selected, and data regarding imaging appearance (abdominal ultrasound or computed tomography), drainage technique, inflammatory markers and clinical course were reviewed and assessed.

The initial imaging work-up was done by abdominal ultrasound and computed tomo- graphy, to determine the location, number and size of the abscess.

After coagulation profile assessment and coagulopathy correction, an informed written consent was signed by the patient. All drainage procedures were performed in the radiology department, under ultrasound and fluoroscopically guidance and local anaesthesia with lidocaine $1 \%$. The shorter transparenchymal path to the abscess was chosen, aiming the gravity-dependent part of the collection and the avoidance of vascular structures. The percutaneous puncture was made with a Chiba needle (sized 18 to 21 Gauge) and abscess fluid was aspirated for bacteriological exam. A Seldinger technique was used to place a self-locking pigtail catheters (sized 10, 12 or 14 French; the catheter diameter was chosen by the interventional radiologist according to the viscosity and the appearance of the material resulted from the initial needle aspiration). Once the position of the catheter was verified by injection of contrast medium, abscess fluid was aspirated. The catheter was then secured to the skin and a 3-way stopcock was adapted to ensure the continuous external drainage in a drainage bag and catheter flushing (Fig. I).

Figure 1. Percutaneous drainage of liver abscess by Seldinger technique
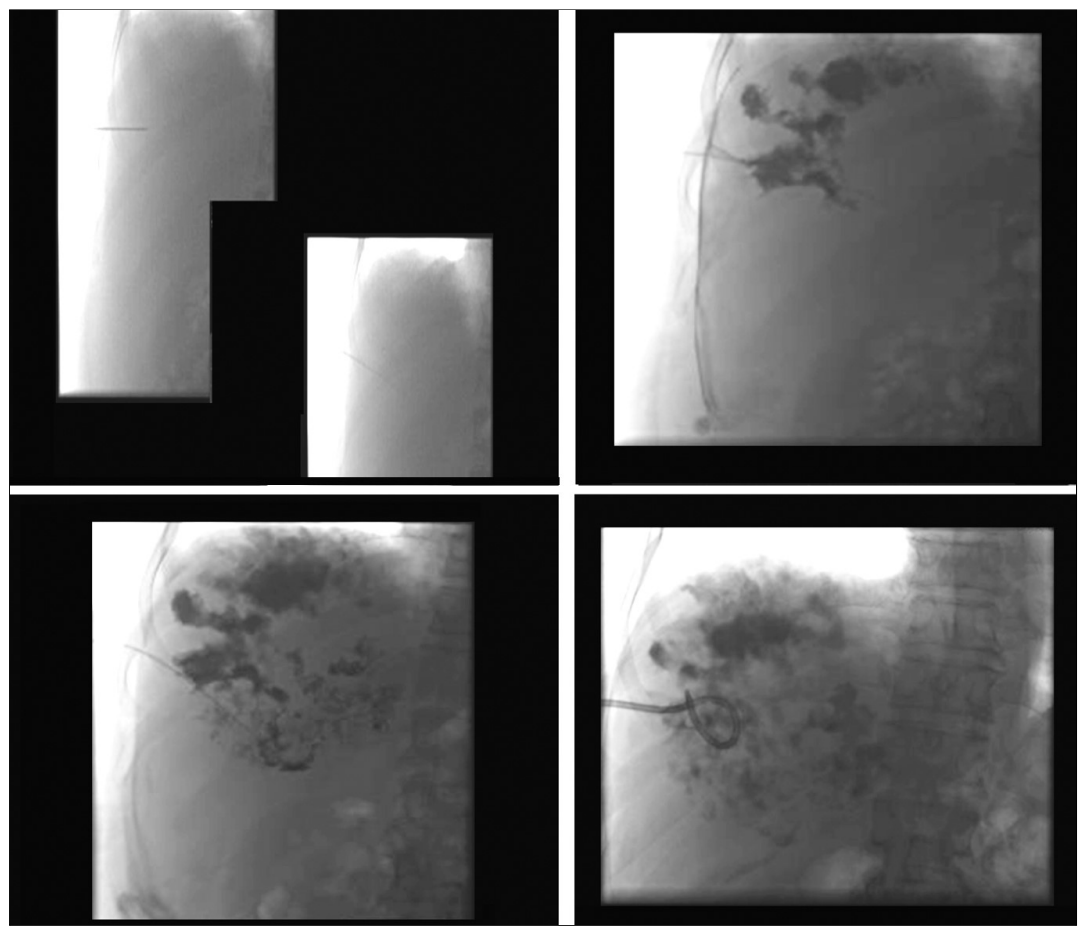

Chirurgia, 116 (4), 2021 
Drainage catheter was flushed every 8 hours with $5-10 \mathrm{~mL}$ of saline solution to ensure its patency and once a day with $10 \mathrm{~mL}$ acetylcysteine in dilution 1:1 with saline to increase fluidity of the abscess content. Catheter management was performed both by the interventional radiologist and the referring surgical team, with the radiologist following up periodically the position of the catheter and the size of the cavity by ultrasound. Specific antibiotherapy was administered according to bacterial or fungal sensitivity.

The effectiveness of this procedure was assessed by the amount of drainage and by the evolution of the cavity.

When catheter output decreased under 10 $\mathrm{mL}$ per day and ultrasound confirmed resolution of the fluid collection, the catheter was removed.

\section{Results}

A total of 21 patients were treated for complex liver abscess with ultrasound-guided percutaneous drainage and intracavitary acetylcysteine between 2015 and 2021 in Surgical Clinic I-II, St. Spiridon Hospital, Iasi.

A total number of 28 lesions were diagnosed by $\mathrm{CT}$ in both lobes; 23 abscesses, sized 8 to $17 \mathrm{~cm}$, were drained, mainly in the right lobe; 4 lesions in the left lobe and one in segment I were under $4 \mathrm{~cm}$ and responded to the medical treatment. The patient parameters are presented in Table 1.
Table 1. Patient characteristics

\begin{tabular}{ll}
\hline Age & $59.3 \pm 13.8$ \\
\hline Gender, male & $14(66.6)$ \\
\hline Coexisting diseases & \\
$\quad$ - Type 2 diabetes mellitus & $9(42.8)$ \\
$\quad$ - Neoplasia (breast, colon, rectum, gastric) & $5(23.8)$ \\
$\quad$ - Arterial hypertension & $7(33.3)$ \\
$\quad$ - Severe anemia (HGB < 70 g/L) & $3(14.2)$ \\
\hline Presenting symptoms, $\mathrm{n}(\%)$ & \\
$\quad$ - Fever & $19(90.4)$ \\
$\quad$ - Abdominal pain & $15(71.4)$ \\
$\quad$ Weakness & $7(33.3)$ \\
\hline Abscess size (mm) & $8-17($ mean 11.6$)$ \\
\hline Abscess number, $\mathrm{n}(\%)$ & 28 \\
$\quad$ Single & $18(85.7)$ \\
$\quad$ Two & $2(7.15)$ \\
$\quad$ Three & $2(7.15)$ \\
\hline Abscess location, $\mathrm{n}(\%)$ & $17(80.9)$ \\
$\quad$ Right lobe & $4(19.1)$ \\
$\quad$ Left lobe &
\end{tabular}

In all cases, the fluid aspirated from the abscess was analysed in the Department of Bacteriology; fungal infection was isolated in 2 patients, and bacterial infection in 19 patients, predominantly by Klebsiella pneumoniae (Graph 1). All patients with fever had blood specimen taken during fever followed by blood culture and in 5 patients was confirmed a positive blood culture with the same bacteria isolated from the pus.

Clinical and radiological resolution was achieved within 14 to 29 days, as a primary success in 19 cases (Fig. 2). Follow-up CT imaging was performed in 2 patients who were not improving their clinical status, and the residual non-drained cavity was shown.
Graph 1. Microbiological analysis of abscess content

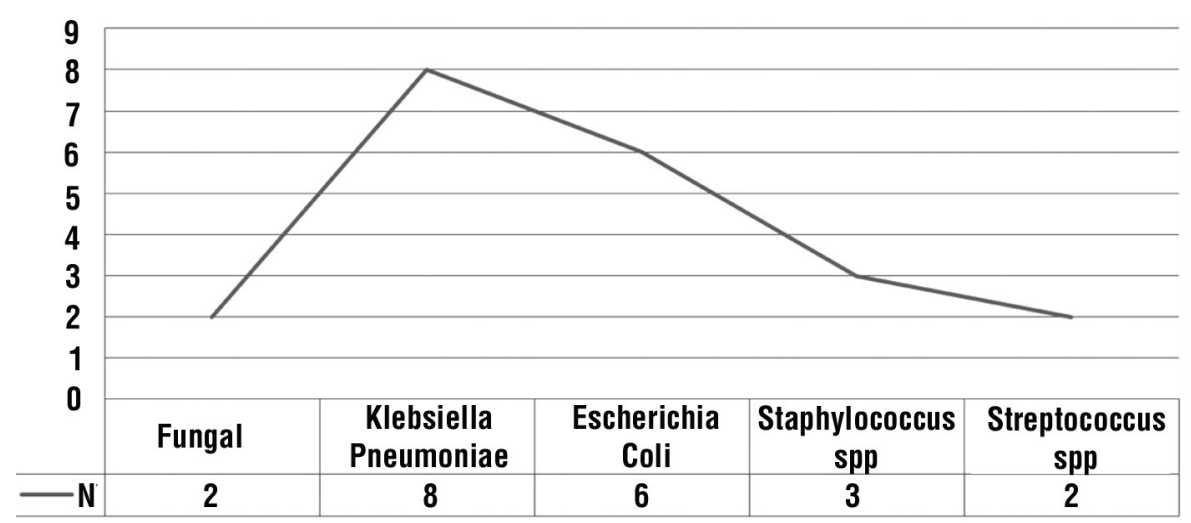

www.revistachirurgia.ro 


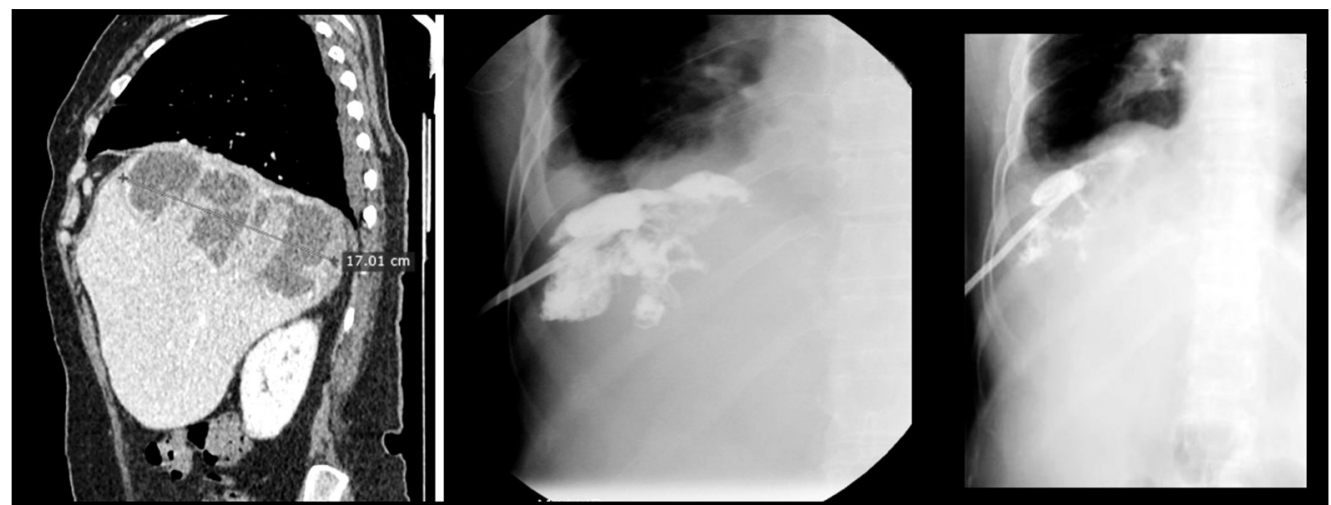

Figure 2. Drainage of a multiloculate abscess - follow-up: CT before drainage - large collection in the right lobe; contrast-medium injection into the cavity 5 days and 12 days after percutaneous placement of catheter showing decreasing of the cavity and of the number of septae

These two cases required supplementary drainage of the non-communicating residual cavity, performed in the same session with the extraction of the first catheter, day 7 and 12 , respectively. Both achieved secondary success, no additional surgical treatment being necessary.

There were no complications, periprocedural deaths or relapse at 3 months follow-up.

\section{Discussion}

The first description of the surgical approach of liver abscess was made in 1938, but this type of drainage was associated with high rates of mortality, 60-80\% (11). The developments in antibiotic therapy, radiology techniques, and interventional radiology, with percutaneous aspiration of a sample necessary for the microbiological examination and to establish the targeted antibiotic reduced the death rates to $5^{-}$ $30 \%$ (12). Multiple or multiloculated abscesses are still considered complex situations both for surgery and interventional radiology, lowering the chances of success (10). But the lower rate of complications and mortality of percutaneous drainage has made the surgical approach less atractive and reserved for the unaccessible positions in the right hepatic lobe, limitation of the maneuverality due to duodenal angulation or multiple abscesses (13).

Image-guided percutaneous drainage of a hepatic collection is the treatment of choice for lesions larger than $4 \mathrm{~cm}$, in the absence of contraindications (severe coagulopathy, severe cardiopulmonary disfunction, hemodynamic instability, lack of a safe pathway to the abscess, patient refusal of procedure (10). A curative drainage is defined by the complete resolution of the infection, with no further need for surgery (10). The ultrasound guidance has many advantages, making this technique a gold standard procedure for single liver abscesses, due to clear localization of abscess and needles, real-time and direct demarcation of liver structures and the path of the needle into the cavity (14). A limit of the ultrasound guidance is represented by the monomicrobial Klebsiella pneumoniae abscesses, when the lesion may appear solid and, therefore, the choise of the larger compartment to drain is difficult (15).

The decision of percutaneous drainage of multiloculated abscesses must be tailored by some factors, as the size, the patient comorbidity or guided accessibility. For complex multiloculated collections refractory to simple catheter drainage, the use of adjunct fibrinolytic agents may increase the rate of succes (16).

Our study assessed the use of a mucolytic agent in the management of percutaneous drained multiloculated liver abscesses as an accelerator for an efficient drainage. The chemical debridement of intracavitary detritus ascertained a progressive and more rapidly decrease of this type of collection, to the ultra- 
sound and radiological control. Acetylcysteine (N-acetyl-L-cysteine) exerts an intense mucofluidizing action at the mucus and mucopurulent secretions, by depolymerization of mucoprotein complexes and nucleic acids that increase the viscosity of the aqueous and purulent component of secretions (17). Additional properties are reduction of induced hyperplasia of mucosal cells, direct antioxidant action, consisting of a nucleophilic thiol group (-SH) capable of direct interaction with electrophilic groups of oxygen free radicals (18). Moreover, the molecular structure allows acetylcysteine to easily cross the cell membrane (19).

Acetylcysteine also exerts an indirect antioxidant effect through its role as a GSH precursor. GSH is a highly reactive, ubiquitous peptide, spread in various tissues of animals, essential for maintaining the functional capacity and morphological integrity of the cell. This is the most important intracellular defense mechanism, both exogenous and endogenous against oxygen free radicals and numerous cytotoxic substances, including paracetamol $(20,21)$.

Finding techniques which can fast the rate of resorption of the abscess content and cavity, reducing the duration of the drainage and of the hospital stay represent a point of interest. The usage of lithic substances which can lower the viscosity of the content and dislocates the intracavitary septa may extend the indications for percutaneous drainage of complex liver abscess. Our study showed that the instillation of acetylcysteine is associated with a length of drainage less than 30 days even for large complex abscesses, a rate of success of $100 \%$, without complications and recurrences after catheter removal.

\section{Conclusion}

Percutaneous drainage is recommended by its simplicity, effectiveness, and fewer procedural-related complications in the management of complex liver abscess and association with intracavity instillation of mucolytic substances is increasing the rate of success and is accelerating the healing of liver abscesses. Further studies are required to compare the efficacy of acetylcysteine with other fibrinolytic substances in quality improvement of the drainage of the multiloculate liver abscess.

\section{Author's Contributions}

All the authors had an equal contribution in this article.

\section{Conflict of Interest}

The authors declare no conflicts of interests.

\section{Ethics Approval}

This study was done by following the ethical norms of scientific research and the principles of confidentiality.

\section{References}

1. Krige JE, Beckingham IJ. ABC of diseases of liver, pancreas, and biliary system. BMJ. 2001;322(7285):537-40

2. Huang CJ, Pitt HA, Lipsett PA, Osterman Jr FA, Lillemoe KD, Cameron JL, et al. Pyogenic hepatic abscess. Changing trends over 42 years. Ann Surg. 1996:223(5):600-7; discussion 607-9

3. Webb GJ, Chapman TP, Cadman PJ, Gorard DA. Pyogenic liver abscess. Frontline Gastroenterol. 2014:5(1):60-7.

4. Ahmed S, Chia CL, Junnarkar SP, Woon W, Shelat VG. Percutaneous drainage for giant pyogenic liver abscess--is it safe and sufficient. Am J Surg. 2016;211(1):95-101.

5. Du ZQ, Zhang LN, Lu Q, Ren YF, Lv Y, Liu XM, et al. Clinical Charateristics and outcome of pyogenic liver abscess with different size: 15-year experience from a single center. Sci Rep. 2016;6:35890. Sci Rep. 2016;6:35890.

6. Yu SC, Ho SS, Lau WY, Yeung DTK, Yuen EHY, Lee PSF, et al. Treatment of pyogenic liver abscess: prospective randomized comparison of catheter drainage and needle aspiration. Hepatology. 2004:39(4):932-8.

7. Kulhari M, Mandia R. Prospective randomized comparative study of pigtail catheter drainage versus percutaneous needle aspiration in treatment of liver abscess. ANZ J Surg. 2019;89(3):E81-6.

8. Malik AA, Bari SU, Rouf KA, Wani KA. Pyogenic liver abscess: changing patterns in approach. World J Gastrointest Surg. 2010;2(12):395-401.

9. Singh P, Tapasvi C, Kaur R, Aggarwal S, Nagpal N, Kaur R. Prospective Randomized Comparison of Ultrasound-Guided Percutaneous Needle Aspiration with Percutaneous Catheter Drainage of Liver Abscesses. J Med Sci. 2019:39(2):67-73.

10. Dariushnia SR, Mitchell JW, Chaudry G, Hogan MJ. Society of Interventional Radiology Quality Improvement Standards for Image-Guided Percutaneous Drainage and Aspiration of Abscesses and Fluid Collections. J Vasc Interv Radiol. 2020;31(4):662-666.e4.

11. Ochsner A, DeBakey M, Murray S. Pyogenic abscess of the liver II. An analysis of forty-seven cases with review of the literature. Am J Surg 1938; XL:292-319.

12. Jepsen P, Vilstrup H, Schønheyder HC, Sørensen HT. A nationwide study of the incidence and 30-day mortality rate of pyogenic liver abscess in Denmark, 1977-2002. Aliment Pharmacol Ther. 2005;21(10):1185-8.

12. Qian $\mathrm{Y}$, Wong CC, Lai S, Chen H, He X, Sun L, et al. A retrospective study of 
pyogenic liver abscess focusing on Klebsiella pneumoniae as a primary pathogen in China from 1994 to 2015. Sci Rep. 2016;6:38587.

13. Ivanina E, Mayer I, Li J, et al. EUS-guided drainage of hepatic abscess. Gastrointest Endosc 2012; 75(4): AB114.

14. Medrado BF, Carneiro FOAA, Vilaca TG, Gouveia TS, Frazăo MSV, de Moura EGH, et al. EUS-guided drainage of giant liver abscess associated with transgastric migration of a self-expandable metallic stent. Endoscopy. 2013; 45 Suppl 2:E331-2

15. Hui JY, Yang MK, Cho DH, Li A, Loke TKL, Chan JCS, et al. Pyogenic liver abscesses caused by Klebsiella pneumoniae: US appearance and aspiration findings. Radiology. 2007;242(3):769-76.

16. Beland MD, Gervais DA, Levis DA, Hahn PF, Arellano RS, Mueller PR. Complex abdominal and pelvic abscesses: efficacy of adjunctive tissue-type plasminogen activator for drainage. Radiology. 2008:247(2):567-73.

17. Abdel-Daim MM, Dessouki HG, Abdel-Rahman R, Eltaysh AA, Alkahtani S Hepatorenal protective effects of taurine and $\mathrm{N}$-acetylcysteine against fipronil- induced injuries: The antioxidant status and apoptotic markers expression in rats. Sci Total Environ. 2019;650(Pt 2):2063-2073.

18. Aldini AG, Altomare, Baron G, Vistoli G, Carini M, Borsani M, et al. NAcetylcysteine as an antioxidant and disulphide breaking agent: The reasons why. Free Radic Res. 2018;52(7):751-762.

19. Bhatti J, Nascimento B, Akhtar U, Ghind SG, Tien H, Nathens A, et al. Systematic review of human and animal studies examining the efficacy and safety of $\mathrm{N}$ acetylcysteine (NAC) and N-acetylcysteine amide (NACA) in traumatic brain injury: Impact on neurofunctional outcome and biomarkers of oxidative stress and inflammation. Front Neurol. 2018:8:744.

20. Ahmed S, Chia CL, Junnarkar SP, Woon W, Shelat VG. Percutaneous drainage for giant pyogenic liver abscess: is it safe and sufficient? Am J Surg. 2016;211(1):95-101.

21. Amaral EP, Conceiçăo EL, Costa DL, Rocha MS, Marinho JM, Cordeiro-Santos $\mathrm{M}$, et al. N-acetyl-cysteine exhibits potent anti-mycobacterial activity in addition to its known anti-oxidative functions. BMC Microbiol. 2016;16(1):251. 